\title{
Information Technology and Libraries at 50: The 1970s in Review
}

What a pleasure it has been to scan through a decade of articles, communications, and news from the ten volumes comprising the 1970s' Journal of Library Automation, predecessor to Information Technology and Libraries. Despite the open-access availability of several of these volumes, I requested the entire run from our high density storage library and delighted in the dusty covers between my hands and the musty smells wafting from the paper and ink. At the same time, I rued past practices at this university library of slicing out journal covers and front and back advertising in order to save a few cents in bindery costs. Such a loss of information about a journal's history!

By the end of the 1970s, I was almost through my undergraduate degree and intended to pursue a library science degree after a gap year, not being able to imagine a more inspiring or satisfying place to build a career than an academic library. Even as an avid library user at that time, I realized that technology was having an increasing impact on operations but, until reviewing these ten years of the journal, did not grasp the tipping point reached. The decade began with tentative language around technology including uncertainty about whether this phenomenon was best called mechanization or automation. That uncertainty extended to the naming of new things, resulting in words not yet joined, or if joined, then with hyphenation: data base or data-base, key word or key-word, on line or on-line, for example. In the early years, the profession began to imagine the coming together of disparate small library applications into what was referred to as a "total" system; the Integrated Library System or ILS had neither been imagined nor articulated.

Early concerns in the decade focused on the rising costs of library services alongside the high price of computing. Cost-benefit analysis drove many decisions related to library automation. In a 1970 article conceptualizing an online catalog, Frederick Kilgour claimed that the "productivity of library workers is not continuously increasing as is that of workers in the general economy" ${ }^{1}$ and concluded that "mechanization, or more specifically, computerization, is the only avenue that extends toward the goal of economic viability." ${ }^{2}$ Fortunately, the decade saw considerable advances in computer engineering coinciding with steadily decreasing costs in processing power, data storage and networking. Nine year later, computer scientist G. Salton imagined a much more viable future for libraries, "postulating a completely new library design where the shelf arrangement of books and journals would be replaced by a computerized store containing presumably the full text of all library items together with appropriate search methodologies." 3

While several decades would pass before the emergence of Project Gutenberg and other mass book scanning projects, technology was sufficiently affordable for libraries by the end of the 1970s that the focus shifted to ways of working cooperatively to harness the powerful new opportunities. JoLA attracted articles on library networks, cataloguing cooperatives, union serial lists, robust circulation systems, early interlibrary loan systems, and commercial and not-for-profit database services. Many applications and systems grew out of projects begun at university and other libraries, but the decade also saw the early emergence of vendor solutions. By the final volume of the 1970s, Caryl and Stratton McAllister reported on

Sandra Shores (sandra.shores@ualberta.ca), a member of LITA and the ITAL editorial board, is Senior IT \& Facilities Officer, Learning Services, University of Alberta. 
DOBI/LIBIS, "an integrated library system with strong authority file control that can be used directly by the library staff and its borrowers." 4 The ILS was born.

A few professional themes that still resonate today stand out from this glance into the past, the first being a shift from valuing ownership of materials to valuing cooperation and resource sharing. Technology combined with an increasing emphasis on standards of description and communication offered new possibilities for regional and national resource sharing, leading many in the profession to acknowledge the futility of trying to build comprehensive collections for their institutions. A number of articles highlight the impact of technology on library personnel, noting that the introduction of automation is disruptive to staff, leaving many feeling unprepared to succeed in their jobs. The roots of evidence-based decision making can be seen in a few articles, for example one describing how newly available data from first generation circulation systems can inform the acquisition of additional copies of high demand titles. ${ }^{5}$ The library user comes more into focus as the decade progresses, in studies about user satisfaction with mediated search and retrieval services, whether run in batch mode or online, and in concept papers imagining systems that support end-user searching. Other articles express concern over the costs of online searching and other computer services, especially as the costs of library materials continued to rise and journals consumed more of the collections budget. Finally, members of the profession understood early that data about use of library materials stored in computer systems needs protection. At the ALA Midwinter meeting in 1973, the Information Science and Automation Division (precursor to LITA) passed a motion urging ALA to develop data privacy policy, noting the "vulnerability of machine-readable files due to the large quantity of data processed."6

William Mathews provides an excellent article to read in anticipation of library technologies in the 1980s. With considerable prescience in "Advances in Electronic Technologies" he takes the reader through microprocessors, high performance computing, the pending home computer phenomenon and new storage and processing technologies. ${ }^{7}$ By the end of the 1970s, the library world was on the cusp of a technology revolution! In bringing this review to a close, I would be remiss not to draw attention to the illustrious professionals who assumed editorial roles in the early years of the journal. Frederick Kilgour, Henriette Avram, Verner Clapp, Pauline Atherton, and others not only had extraordinary careers but also set high standards for the journal and the association. Kudos to them for their establishment of JoLA!

${ }^{1}$ Frederick G. Kilgour, “Concept of an On-line Computerized Library Catalog,” Journal of Library Automation 3, no. 1 (March 1970): 2, https://doi.org/10.6017/ital.v3i1.5123.

${ }^{2}$ Kilgour, "Concept," 3.

${ }^{3}$ G. Salton, “Suggestions for Library Network Design,” Journal of Library Automation 12, no. 1 (March 1979): 39-40.

${ }^{4}$ Caryl McAllister and A. Stratton McAllister, "DOBIS/LIBIS: An Integrated, On-Line Library Management System," Journal of Library Automation 12, no. 4 (December 1979): 300.

${ }^{5}$ Robert S. Grant, “Predicting the Need for Multiple Copies of Books, Journal of Library Automation 4, no. 2 (June 1971): 64-71, https://doi.org/10.6017/ital.v4i2.5583.

6 "Highlight of Minutes: Information Science and Automation Division, Board of Directors Meeting," Journal of Library Automation 6, no. 1 (March 1973): 57, https://ejournals.bc.edu/ojs/index.php/ital/article/view/5761/5140.

7 William D. Mathews, “Advances in Electronic Technologies,” Journal of Library Automation 11, no. 4 (December 1978): 299-307. 